\title{
COMPARATIVE DISTRIBUTION OF OPIATE RECEPTORS AND THREE OPIOID PEPTIDE NEURONAL SYSTEMS IN RHESUS MONKEY CENTRAL NERVOUS SYSTEM
}

Michael E. Lewis, Henry Khachaturian and Stanley J. Watson

Mental Health Research Institute

University of Michigan

Ann Arbor, Michigan 48109

(Received in final form June 26, 1983)

\section{Summary}

Using combined autoradiography-immunocytochemistry, the anatomical distribution of $\left[{ }^{3} \mathrm{H}\right]$ naloxone-labelled opiate receptors was compared to the loci of neuronal systems immunoreactive for $\beta$-endorphin, [Leu] enkephalin and dynorphin A in rhesus monkey brain. High densities of binding were observed in relation to each of the systems, consistent with findings that each opioid precursor can synthesize one or more peptides with substantial (though not selective) activity at $\mu$ receptors.

There is now impressive evidence for a multiplicity of functional roles of endogenous opioid peptides (1), although much about their physiology and pathophysiology still remains obscure. This is particularly so for primates since most studies have focused upon rodents. While anatomical studies of opioid peptides and receptors have been useful in the formulation of specific hypotheses about the functions of opioid systems $(e .8 ., 2-4)$, only a few of these studies have been carried out in primates $(2,5-8)$.

Investigators of opioid systems must contend with the existence of three genetically distinct opioid peptide precursors (see ref. 1 for review): proopiomelanocortin, which gives rise to $\beta$-endorphin; proenkephalin, which contains seven peptides with the [Met]- or [Leu]enkephalin active core; and prodynorphin, which produces three opioid peptides ( $\alpha$-neo-endorphin, dynorphin $A$, and dynorphin $B$ ) containing the [Leu] enkephalin sequence. Enkephalin systems have been carefully mapped in rhesus monkey brain (7), but $\beta$-endorphin systems have been less well characterized (8), and dynorphin systems have not been described at all in primate brain. Recent autoradiographic studies have mapped the anatomical distribution of opiate receptors in monkey brain $(5,6)$, although these investigations did not explore the differential distribution of receptor subtypes $(2,3,9)$ for which the endogenous opioids show apparently different affinities ( 9 ). Given the complexity of endogenous opioid systems (i.e., different systems of neurons containing genetically distinct precursors giving rise to a variety of opioids which may act differentially at multiple receptors), it is essential to anatomically characterize these systems in relation to each other, including the receptors. We have been carrying out comparative autoradiographic-immunocytochemical studies of opioid systems in adjacent sections of rat brain (10), and present here the results of such studies in rhesus monkey brain. 


\section{Methods}

Adult rhesus monkeys (Macaca mulatta) were anesthetized with sodium pentobarbital ( $30 \mathrm{mg} / \mathrm{kg}, i . v$.$) , respirated, and perfused through the aorta$ with 2 liters of saline followed by 16 liters of 0.1 M phosphate-buffered $4 \%$ formaldehyde. Some animals were treated, under anesthesia, with colchicine (1-3 $\mathrm{mg}$, intracerebroventricularly) 48 hours prior to perfusion. The brains were blocked, postfixed in buffered formaldehyde for $2-4$ hours at $4^{\circ} \mathrm{C}$, incubated in buffered $15 \%$ sucrose overnight at $4{ }^{\circ} \mathrm{C}$, frozen in isopentane at $-50^{\circ} \mathrm{C}$, sectioned at 20 microns in a cryostat at $-20^{\circ} \mathrm{C}$ and thaw-mounted onto subbed slides which were then stored at $-70^{\circ} \mathrm{C}$. Peroxidase-antiperoxidase immunocytochemistry was carried out as described (11), using antisera against proopiomelanocortin (POMC) peptides ( $\beta$-endorphin, ACTH, and $\alpha-M S H)$, proenkephalin (ENK) peptides ([Leu]enkephalin and BAM-22P) and prodynorphin (DYN) peptides (dynorphin $A$ and $\alpha$-neo-endorphin). The characteristics of these antisera have been described elsewhere $(4,11,12)$; preadsorption controls were also carried out as before $(4,11,12)$. Sections adjacent or near to those processed for immunocytochemistry were labelled with $\left[{ }^{3} \mathrm{H}\right]$ naloxone and processed for autoradiography as described elsewhere $(3,10,13)$.

\section{$\underline{\text { Results }}$}

When the anatomical distribution of $\left[{ }^{3} \mathrm{H}\right]$ naloxone-labelled sites was compared to the loci of immunoreactivity for the three classes of opioid peptides, we observed variations in binding site density with different opioid systems in different brain regions (Table I, Figure 1). The POMC system is anatomically associated with $\left[{ }^{3} \mathrm{H}\right]$ naloxone binding sites in many regions. High densities of $\left[{ }^{3} \mathrm{H}\right]$ naloxone binding were also observed in regions containing ENK and DYN (but not POMC) immunoreactive systems, e.g., in interpeduncular nucleus and the nucleus of the spinal tract of the trigeminal nerve, as well as in regions containing primarily DYN immunoreactivity (including perikarya), e.g., in supraoptic nucleus and paraventricular nucleus of hypothalamus. In general, the POMC, ENK and DYN systems each showed a characteristic pattern of distribution which was consistent for each set of precursor-related antisera.

\section{Discussion}

We have detected a complex distribution of stereospecific $\left[{ }^{3} \mathrm{H}\right]$ naloxone binding sites in formaldehyde-perfused rhesus monkey brain (Fig. 1, Table I) similar to that reported by Wamsley et ${ }^{2}$. (6) for $\left[{ }^{3} \mathrm{H}\right]$ diprenorphine sites in unperfused cynomolgus monkey. While $\left[{ }^{3} \mathrm{H}\right]$ diprenorphine appears to label all subtypes of opiate receptors (9), [ $\mathrm{H}$ ]naloxone apparently labels a pharmacologically (if not anatomically) more discrete group of sites (mostly $\mu$; 13, 14), particulary since $4 \%$ formaldghyde perfusion abolishes virtually all specific binding of $\left[{ }^{3} \mathrm{H}\right] \mathrm{D}-\mathrm{Alg} \mathrm{a}^{2}$, D-Leu -enkephalin to brain sections (Lewis, Khachaturian and Watson, in preparation). The anatomical association between $\left[{ }^{3} \mathrm{H}\right]$ naloxone sites and $\beta$-endorphin immunoreactivity was not unexpected since $\beta$-endorphin has been shown to interact with $\mu$ receptors in vitro (9) and many $\beta$-endorphin effects in vivo are naloxone-reversible (1). However, the association between these sites and enkephalin immunoreactivity, as we reported previously for rat brain (10), does not fit the prediction based on the preferential affinity of the pentapeptide enkephalins for the $\delta$ receptor (9). This association is less paradoxical given the recent findings of substantial $\mu$ activity of the enkephalin octapeptide (Kosterlitz, unpublished; Young et al., unpublished). Similarly, the anatomical association between [ $\left.{ }^{3} \mathrm{H}\right]$ naloxone binding sites and dynorphin immunoreactivity might not have been predicted 
Comparative Distribution of $\left[{ }^{3} \mathrm{H}\right] \mathrm{Naloxone}$ (NAL) Binding Sites and POMC, ENK and DYN Immunoreactivity in Selected Rhesus Monkey CNS Regions

\begin{tabular}{|c|c|c|c|c|}
\hline REGION & {$\left[{ }^{3} \mathrm{H}\right] \mathrm{NAL}$} & POMC & ENK & DYN \\
\hline Caudate nucleus & ++ & + & ++ & $++t$ \\
\hline Putamen & ++ & + & ++ & ++ \\
\hline Globus pallidus & + & 0 & +++ & +++ \\
\hline Medial preoptic area & ++ & ++ & ++ & ++ \\
\hline Lateral preoptic area & ++ & + & ++ & + \\
\hline Bed nuc. stria terminalis & ++ & +++ & ++ & + \\
\hline Median eminence, ext. zone & +++ & ++ & $++t$ & ++ \\
\hline Paraventricular nuc., hypothal. & +++ & ++ & + & +++ \\
\hline Arcuate nucleus & +++ & +++ & +++ & ++ \\
\hline Supraoptic nucleus & +++ & 0 & + & +++ \\
\hline Periventricular hypothal area & +++ & +++ & ++ & ++ \\
\hline Lateral hypothal. area & ++ & ++ & + & + \\
\hline Ventromedial hypothal. area & ++ & + & ++ & + \\
\hline Posterior hypothal. area & ++ & + & ++ & + \\
\hline Paraventricular nuc., thal. & +++ & +++ & +++ & + \\
\hline Periaqueductal grey & ++ & ++ & +++ & + \\
\hline Interpeduncular nuc. & +++ & 0 & ++ & + \\
\hline Dorsal raphe nucleus & ++ & ++ & ++ & + \\
\hline Parabrachial nuclei & +++ & + & ++ & + \\
\hline Nuc. tractus solitarius & ++ & ++ & +++ & ++ \\
\hline Area postrema & ++ & 0 & + & + \\
\hline Nuc. of spinal tract of $V$ & +++ & 0 & ++ & ++ \\
\hline Dorsal horn, spinal cord & +++ & + & ++ & ++ \\
\hline
\end{tabular}

(density: 0 = undetectable; + = light; ++ = medium; +++ = heavy).

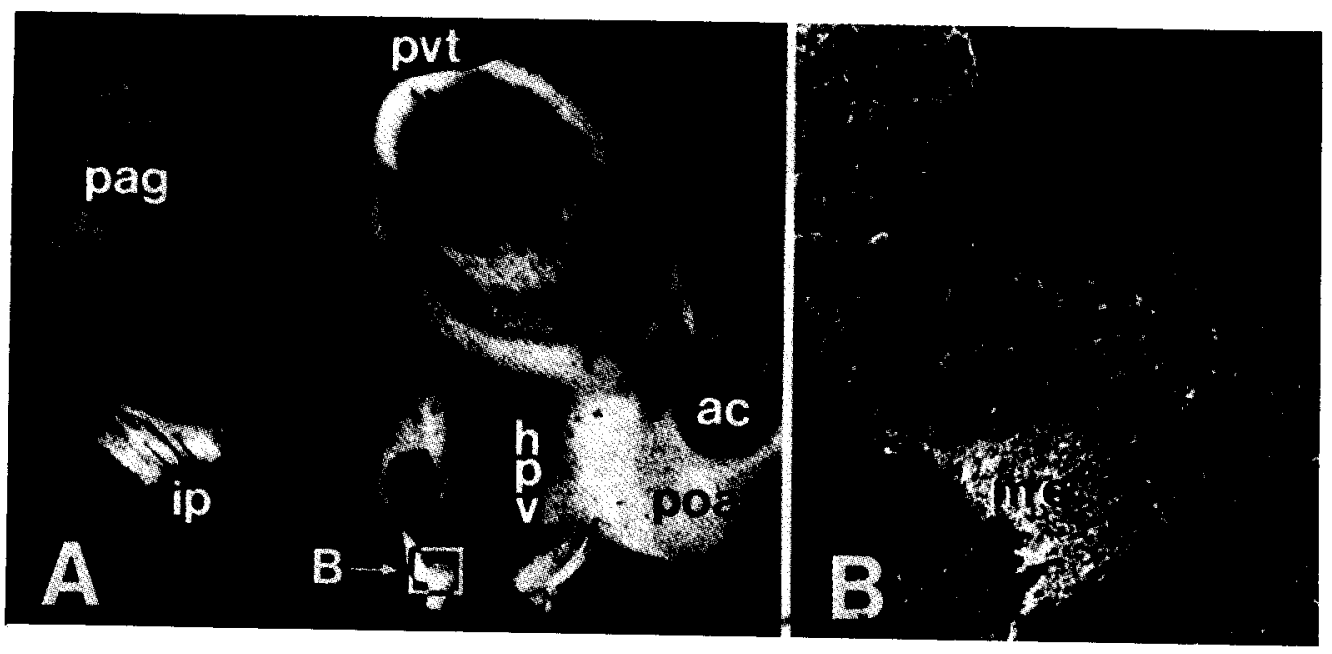

FIG. 1

Figure 1. A: $\left[{ }^{3} \mathrm{H}\right]$ naloxone binding in a midline sagittal section of rhesus monkey brain. B: ACTH immunoreactivity in enlarged view of arcuate nucleus, corresponding to box (B) in A. ac: ant. commissure; hpv: perivent. hypoth.; ip: interped. n.; me: med. eminence; pag: periaqueductal grey; poa: preoptic area; pvt: paravent. thal. 
since dynorphin $A$ has been reported to be a $\kappa$ ligand in vitro (e.g., 15); however dynorphin $A(1-13)$ has been reported to interact with $\mu$ sites under some conditions $(16,17,18)$, and dynorphin $A(1-8)$, which is much more plentiful endogenously than dynorphin A (ref. 19), also has considerable $\mu$ activity (18; Quirion and Weiss, unpublished). In short, given the capacity of each of the three opioid precursors to synthesize peptides with $\mu$ activity, it is not surprising to find an anatomical relationship between the three opioid systems and $\left[{ }^{3} \mathrm{H}\right]$ naloxone-labelled opiate receptors. This finding is consistent with the possibility that multiple products of the same opioid precursor act at different receptor subtypes, a viewpoint compatible with much recent evidence $(1,14,20,21$; Quirion and weiss, in preparation). This viewpoint implies that opiate receptor subtypes will not be individually coupled to different endogenous opioid systems, but rather, that each system can express its activity through multiple receptors, and that peptide processing will be a key regulatory event in determining receptor subtype interactions.

\section{Acknowledgements}

This work was supported by Theophile Raphael Fund to S.J. Watson and NIDA Center grant DAO0154.

\section{References}

1. H. AKIL, S.J. WATSON, E. YOUNG, M.E. LEWIS, H. KHACHATURIAN and J.M. WALKER, Ann. Rev. Neurosci. in press.

2. M.E. LEWIS, M. MISHKIN, E. BRAGIN, R.M. BROWN, C.B. PERT and A. PERT, Science 211 1166-1169 (1981).

3. M.E. LEWIS, A. PERT, C.B. PERT and M. HERKENHAM, J. Comp. Neurol. 216 229-258 (1983).

4. H. KHACHATURIAN, S.J. WATSON, M.E. LEWIS, D. COY, A. GOLDSTEIN and H. AKIL, Peptides 3 941-954 (1982).

5. S.P. WISE and M. HERKENHAM, Science $218387-389$ (1982).

6. J.K. WAMSIEY, M.A. ZARBIN, W.S. YOUNG III and M.J. KUHAR, Neuroscience 7 595-613 (1982).

7. S. HABER AND R. ELDE, Neuroscience 7 1049-1095 (1982)

8. G.M. ABRAMS, G. NILAVER, D. HOFFMAN, E.A. ZIMMERMAN, M. FERIN, D.T. KRIEGER and A.S. LIOTTA, Neurology 30 1106-1110 (1980).

9. L.E. ROBSON, S.J. PATERSON and H.W. KOSTERLITZ, Handbook of Psychopharmacology, p. 13, Plenum Press, New York (1983).

10. M.E. LEWIS, H. KHACHATURIAN and S.J. WATSON, Life Sci. 31 1347-1350 (1982).

11. H. KHACHATURIAN, M.E. LEWIS, V. HOLIT and S.J. WATSON, J. Neurosci. 3 844-855 (1983).

12. S.J. WATSON and H. AKIL, Eur. J. Pharmacol. 58 101-103 (1979).

13. M. HERKENHAM and C.B. PERT, J Neurosci. $21129-1149$ (1982).

14. R. QUIRION, W.D. BOWEN, M. HERKENHAM and C.B. PERT, Cell Mol. Neurobiol. 2 333-346 (1982).

15. C. CHAVKIN, I.F. JAMES and A. GOLDSTEIN, Science 215 413-415 (1982).

16. R. QUIRION and C.B. PERT Eur. J. Pharmacol. $76467-468$ (1981).

17. W.A. HEWLETT, H. AKIL and J.D. BARCHAS, Advances in Endogenous and Exogenous Opiates, p. 36 , Kodansha Ltd., Tokyo and Elsevier Biomedical Press, Amsterdam (1981).

18. A.D. CORBETT, S.J. PATERSON, A.T. MCKNIGHT, J. MAGNAN and H.W. KOSTERIITZ, Nature 299 79-81 (1982).

19. E. WEBER, C.J. EVANS, and J.D. BARCHAS, Nature 299 77-79 (1982).

20. A.P. SMITH, N.M. LEE and H.H. LOH, Trends Pharmacol. Sci. 4 163-164 (1983).

21. R.B. ROTHMAN and T.C. WESTFALL, Mol. Pharmacol. 21 538-557 (1982). 